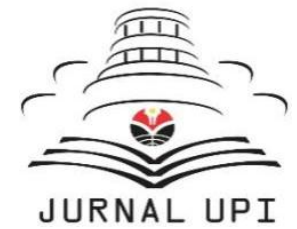

THE JOURNAL GASTRONOMY TOURISM

Volume 7 Issue 1, June 2020, 31-37

Available online at:

https://ejournal.upi.edu/index.php/gastur

Gastronomy Tourism Journal

\title{
The Influence of Flavor on The Purchase Decision Of Bakpia Mutiara Jogja
}

\section{Galuh Pratama ${ }^{1}$}

${ }^{1}$ Sekolah Tinggi Ilmu Pariwisata Ambarrukmo Yogyakarta, Sleman Daerah Istimewa Yogyakarta, Indonesia

*Corresponding Author. E-mail: 19030070@stipram.ac.id (Galuh Pratama)

\begin{tabular}{|l}
\hline ABSTRACT \\
The purpose of this study is to determine the influence of flavor on the purchasing \\
decision of Bakpia Mutiara Jogja. This study uses a quantitative approach. The \\
population of this research are consumers who have bought bakpia at Bakpia Mutiara \\
Jogja store. The sampling technique uses purposive sampling. The sample in this study \\
are 100 consumers who have bought bakpia more than once in Bakpia Mutiara Jogja \\
store. This research using simple regression analysis method. The results shows that \\
flavor have a positive and significant influence on the purchasing decision of Bakpia \\
Mutiara Jogja (sig $=0,000<0.05$ and regression coefficient $=0.432)$. \\
Keywords: Flavor, Purchasing Decision, Bakpia. \\
First Received: \\
January 2020 \\
Final Proof Received: \\
June 2020
\end{tabular}




\section{Introduction}

Industry of food and beverage sector is one of industry that is quite promising for entrepreneurs in Indonesia. Based on data from the Indonesian Food and Beverage Company Association (GAPMMI), sales growth of food and beverage products has increased from year to year to reach $8 \%$. Figures 1 is the sales value of food and beverage products in Indonesia.

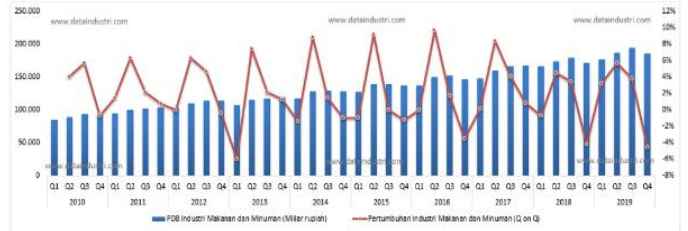

Figures 1. Sales Value of Food and Beverage Products in Indonesia

The Ministry of Industry records the growth of the food and beverage industry in 2019 to reach $7.78 \%$. The sales value of food and beverage products in Picture 1 is higher than the growth of the non-oil and gas industry which is at $4.34 \%$ or the national industry growth of $5.02 \%$. In addition, in the same year, the food and beverage industry sector also contributed up to $36.40 \%$ to the GDP of the non-oil and gas processing industry (Antara News, 2020).

One of Indonesia's local food processing industries is bakpia. Bakpia which is often found in particular, cities such as Yogyakarta, is bakpia patok. Bakpia is a food made from a mixture of mung beans with sugar wrapped in flour and then roasted. The term bakpia comes from the Hokkien dialect, which is from the word "bak" which means meat and "pia" which means cake, which literally means bread containing meat. In some regions in Indonesia, foods that has tender and thick filling are known as pia or pia cake (Prabudi, 2014).

Over time, the traditional food of bakpia has been innovated with various flavors. Not only contains mung beans, now bakpia also contains cheese, chocolate, purple sweet potatoes, and others. Bakpia has become one of the most popular foods that tourists demand when visiting Yogyakarta. According to the Yogyakarta Department of Trade, Industry and Cooperatives (Disperindakop), bakpia industry in Yogyakarta City is a traditional food industry that has the highest business units, namely 68 micro, small and medium enterprises (MSMEs). This is more than other special foods, such as
Gudeg, which consists of 30 MSMEs (pkpp.ristek.go.id).

This research was conducted at Bakpia Mutiara Yogyakarta Shop. The store is a shop that sells bakpia pathok products. Bakpia Pathok Mutiara Jogja is one of the many Bakpia brands in Yogja that is highly recommended to be the choice of tourist handsel when visiting Yogyakarta and the surrounding. Bakpia Mutiara Jogja stores are found in several areas in Yogyakarta, one of which is located in the east of the very famous Prambanan Temple tourist attraction, precisely on Jalan Manisrenggo km.0,5 Prambanan.

Bakpia Mutiara Jogja has several flavors, such as chocolate, green tea, cheese, black kumbu, and mung beans. Chocolate Bakpia is made from real chocolate, it doesn't use any chocolate flavoring ingredients. This bakpia's kumbu (filling) is very soft, delicious, sweet, and crispy skin. In addition, this bakpia can last a minimum of nine days without using preservatives. For chocolate fans, enjoying Bakpia Mutiara Jogja chocolate flavor feels like enjoying the delicious chocolate bar.

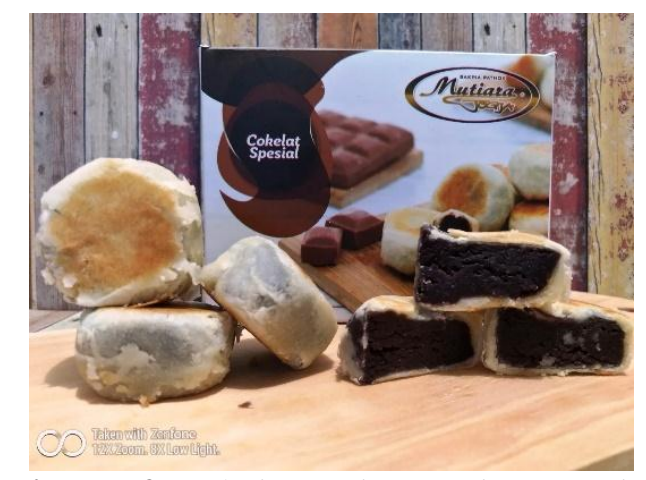

Figures 2. Bakpia Mutiara Jogja - Special Chocolate

The second flavor variant is Bakpia Mutiara Green Tea. When you bite this bakpia, there is a mint flavor that makes the sensation of enjoying bakpia green tea so addictive. Green tea bakpia has its own different sensation. The sensation that feels is a blend of the taste of mung bean bakpia flavored with sweet green tea flavor and a little mint flavor in it so that it gives an experience of enjoying this bakpia. Without using preservatives, this bakpia can last up to a minimum of 7 days and without any change in taste. 


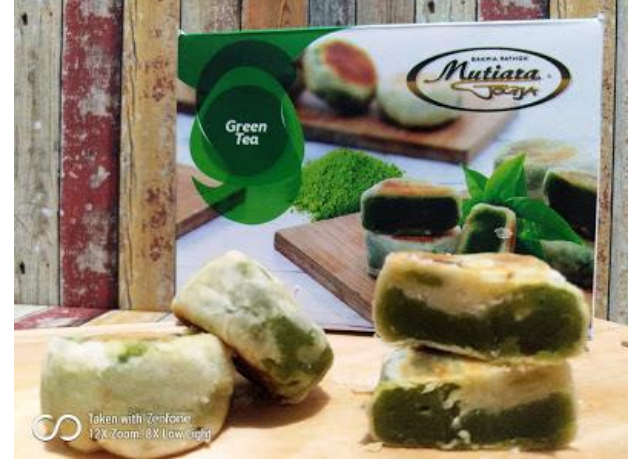

Figures 3. Bakpia Mutiara Jogja - GreenTea

Bakpia Mutiara Jogja also provides a special cheese flavor variant that tastes not too sweet but tends to be savory that is addictive with $100 \%$ pure cheese, high quality, MUI \& BPOM standard. Bakpia customers will definitely not be disappointed because enjoying Bakpia Mutiara Jogja special cheese give the same experience as enjoying the delicious real cheese. Bakpia Mutiara Jogja Special cheese, is soft, sweet, and has crispy skin. With a minimum resistance of 9 days, Bakpia Mutiara Jogja special cheese is very safe for handsel outside the city.

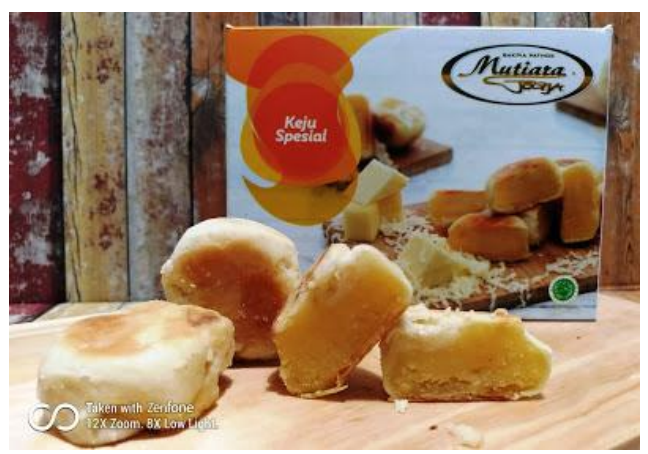

Figures 4. Bakpia Mutiara - Special Cheese

The distinctive taste of black kumbu, especially processed by fitting by Bakpia Mutiara Jogja makes this black kumbu taste more delicious. Made from kidney beans, milk, sugar, and other additional ingredients that have MUI and BPOM standards. Bakpia Mutiara Jogja black kumbu's color is not pitch black like Bakpia black kumbu in general. The black color comes from the original color of the decoction of red beans (tolo beans) which is the raw material of Bakpia Mutiara Jogja black kumbu, Bakpia is without using any food coloring so it is very safe to consume. Bakpia Mutiara Jogja black kumbu tastes delicious, sweet, the kumbu is tender and remains tender even until the expiration date runs out. It can last up to a minimum of 7 days with no preservatives at all.

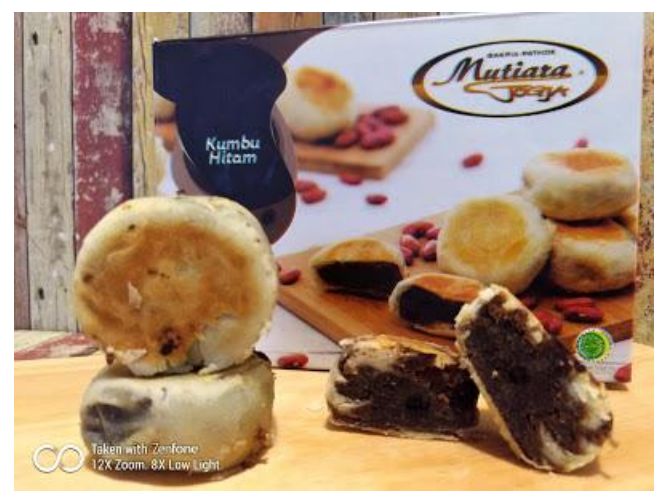

Figures 5. Bakpia Mutiara Jogja - Black Kumbu

Bakpia Mutiara Jogja mung bean's taste is often found. In general, Bakpia is sold in many souvenir centers in Yogja. However, Bakpia Mutiara Jogja is different. The filling of mung beans and crispy crust when entering the mouth, making 1 bite of Jogja bakpia never enough.

Made from selected mung beans, milk, sugar, and other additional ingredients that have MUI and BPOM standard, without using preservatives and coloring so it is safe and halal for consumption. The raw material is the best quality mung beans and through a hygienic washing process so that this bakpia is more durable for at least seven days without any change in taste. When enjoying this bakpia, consumers will feel the delicacy and softness of bakpia that is completely different from other mung bean bakpia.

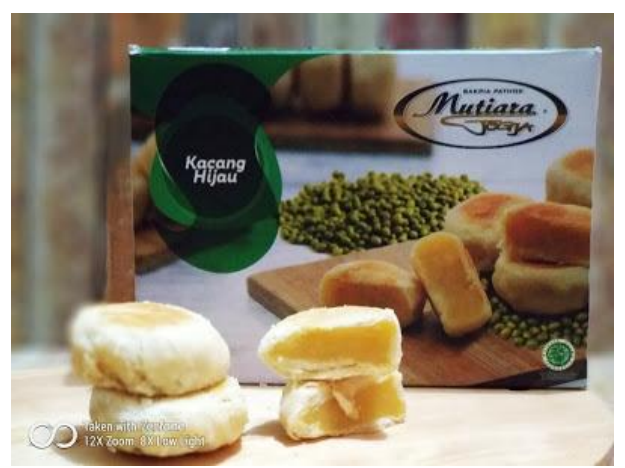

Figures 6. Bakpia Mutiara Jogja -Mung Bean

Bakpia business competition requires Bakpia Mutiara Jogja to improve the performance of its products to increase public purchases. Basically, a purchase decision is an act or behavior of consumers so whether or not to make a purchase or transaction. The number of consumers in making decisions is one of the 
determinants of whether or not the company's goals are achieved. Consumers are often faced with several choices in using a product. This causes consumers to consider carefully before making a decision to buy.

Purchasing decisions are actions of consumers to or not to buy a product (Kotler, 2002). Of the various factors that influence consumers in purchasing products or services, consumers usually always consider the quality, price, and products that are already known by the public. Assael (2001) defines consumer decision making as the process of feeling and evaluating brand information, considering alternative brands to meet consumer needs and deciding on a brand.

Purchase decisions made by customers involve customer confidence in a product so that self-confidence arises over the truth of the actions taken. The customer's confidence in the purchase decision is that they make represents the extent to which the customer has confidence in his decision to choose a product (Kusumastuti, 2011: 2). Consumers, of course, in making purchasing decisions, also consider the factors that influence purchasing decisions. Factors that need to be considered by the company is a sense that can influence consumers to make purchasing decisions for their products.

In bakpia business competition, companies are required to provide innovations in various flavors according to consumer demand. Drummond KE \& Brefere LM (2010) defines that flavor is a way of choosing food that must be distinguished from the taste of the food. Taste flavor is a food attribute that includes appearance, smell, taste, texture, and temperature. Flavor is very important in the sale of Bakpia. The distinctive taste in Bakpia will be its own characteristic for customers or tourist. When going to consume something, the first thing that is assessed is the taste or food quality. Sharp flavor allows one to judge whether the food is suitable for consumption or not. The flavor of bakpia is one of the advantages of bakpia sales which can encourage the purchase of the surrounding community and tourists visiting Yogyakarta.

Based on this explanation, this study aims to determine the influence of flavor on the purchasing decision of Bakpia Mutiara Jogja.

\section{Literature Review}

\subsection{Buying decision}

Decisions, according to Hasan (2002: 9), are the result of resolving the problems he faces explicitly. A decision is a definite answer to a question. Decisions must be able to provide answers to questions about what was discussed in relation to planning. Decision making, according to Terry in Hasan (2002: 12), is the selection of certain alternative behaviors (behaviors) from two or more alternatives. Decision making occurs when a person is faced with several choices and he must choose the one that is most appropriate to meet his wants and needs. Briefly, decision making is a process used to choose an action as a way of solving a problem (Stoner, in Hasan, 2002).

According to Simamora (2002), each buying decision is related to the following five decisions.

1) Decisions about the type of product

Consumers can make a decision to buy the form of products offered by certain companies. The decision also concerns the size, quality, and style. In this case the company must conduct marketing research to find out consumers' preferences about the product in question in order to maximize attractiveness as well.

2) Decisions about the shape of the product

Consumers must make purchasing decisions based on the form of products to be purchased. In this case the company must know how to make the product visuals as attractive as possible.

3) Decisions about brands

Consumers must make decisions about which brands to buy. In this case the company must know how to choose a brand.

4) Decisions about the seller

Consumers must make a decision where the product to be purchased, namely the location of the product being sold.

5) Decisions about the number of products

Consumers can make decisions how many products to buy at a time. In this case the company must prepare products according to consumers different desires. 


\subsection{Flavor}

According to Drummond \& Brefere (2010), flavor is a way of choosing food that must be distinguished from the taste of the food. Flavor is a food attribute that includes appearance, smell, taste, texture, and temperature. A high taste makes a person can judge the taste of the meal is suitable for consumption or not.

Based on the opinion of Drummond \& Brefere (2010), there are five indicators that will be used to measure this flavor variable, namely odor, characteristics, aroma, taste, and texture or shape of the product. The flavor of a food will affect someone with the identity of where the food is produced. With indicators of characteristics, odors, and aromas of taste, consumers can judge that the food consumed has its own characteristics in each region.

\subsection{Influence of Flavor on Purchasing Decisions \\ Flavor is very important in the sale of} bakpia. The distinctive flavor in bakpia will be its own characteristic for customers or consumers. A person's behavior in enjoying everything that is consumed is definitely the first to judge from the food is flavor or food quality. A sharp flavor makes a person can judge whether the meal is suitable for consumption or not. The flavor of bakpia is one of the advantages of bakpia sales which can encourage public purchases. Thus, the higher the taste of bakpia, the purchasing decisions of the people will also be higher.

\subsection{Hypothesis}

The flavor has positive and significant influence on a decision to purchase Bakpia Mutiara Jogja.

\section{Materials and Methods}

\subsection{Types of research}

This research is a quantitative research. Quantitative research is defined as a research method based on the philosophy of positivism, used to examine populations or specific samples, collecting data using research instruments, quantitative / statistical data analysis to test hypotheses that have been set (Sugiyono, 2016).

\subsection{Place and time of research}

This research was conducted at Jln. Manisrenggo km. 0.5, Tlogo, Prambanan. in
June 2020.

\subsection{Population and Research Samples}

The study population was all consumers who had bought bakpia in Bakpia Mutiara Jogja store. The technique used in this research is purposive sampling. The definition of purposive sampling method, according to Sugiyono (2008), is "The technique of determining the sample with certain considerations". The sample of this study is the majority of consumers who have bought Bakpia more than once at bakpia Mutiara Yogyakarta store.

\subsection{Procedure}

Data collection methods used are primary data that contains questions to respondents.

\subsection{Data, Instruments and Data Collection Techniques \\ The data used in this study are primary data.} The technique used to collect data in this study is questionnaire. The research instrument used in this study was a closed questionnaire, respondents only provided a checklist $(\sqrt{ })$ on the alternative answers provided.

\subsection{Data analysis technique}

Validity and reliability tests in this study were conducted on a sample of 100 respondents. Validity test using Pearson Product Moment correlation and reliability testing using Cronbach Alpha. The research hypothesis is processed using a simple linear regression analysis tool to determine the effect of independent variables on the dependent.

\section{Results and Discussion}

4.1. Research result

4.1.1. Normality test (Testing Prerequisite
Analysis)

The results of the normality test for each study variable are presented below.

Table 1.Normality test result

\begin{tabular}{lcc}
\hline \multicolumn{1}{c}{ Variable } & Sig & Explanation \\
\hline Flavor & 0,136 & Normal \\
Purchase & 0,104 & Normal \\
Decision & & \\
\hline
\end{tabular}

Normality test results show that all research variables have a significance value greater than 0.05 at ( $\mathrm{sig}>0.05$ ) so that it can be concluded that the research data is normally distributed. 


\subsubsection{Linearity Test}

The results of the linearity test summary are presented below.

Table 2. Linearity test result

\begin{tabular}{cc}
\hline Variable & Sig. \\
\hline Taste & 0,170 \\
\hline The linearity test results indicate that the
\end{tabular}
significance value of $0.170>0.05$ so that both variables can be said to be linear.

\subsubsection{Hypothesis test}

Hypothesis testing in this study was conducted using simple regression analysis techniques. The results of a simple regression analysis are presented as follows.

Table 3. Simple Linear Regression Results

\begin{tabular}{cccc}
\hline$B$ & $\mathrm{~T}$ & $\mathrm{Sig}$ & $\mathrm{R}^{2}$ \\
\hline 0,432 & 3,656 & 0,000 & 0,328
\end{tabular}

Based on the table above, it can be seen that the $\mathrm{t}$-value is 3.656 ; a significance value of 0,000 is smaller than $0.05(0,000<0.05)$, and the regression coefficient is positive at 0.432 . Hypothesis test results stating that " Flavor has a positive and significant influence on purchasing decisions Bakpia Mutiara Jogja" is accepted.

The table also shows the magnitude of the coefficient of determination (R2). The R2 test results in this study obtained a value of 0.328 . This shows that the purchasing decision is influenced by flavor by $32.8 \%$, while the remaining $67.2 \%$ is influenced by other factors not included in this study, such as price, promotion, and advertising.

\subsection{Discussion}

The results showed that flavor had a positive and significant influence on a decision to purchase Bakpia Mutiara Jogja. Flavor is a way of choosing food that must be distinguished from the taste of the food. Flavor is a food attribute that includes appearance, smell, taste, texture, and temperature (Poerwadarminta, 2010).

Flavor is a form of cooperation among the five types of human beings, namely taste, smell, touch, sight, and hearing. Taste is the result of the work of taste buds located on the tongue, cheeks, esophagus, roof of the mouth which are part of the Flavor. In general, there are four main known, namely sweet, salty, sour, and bitter although there are still possible categories of flavors, such as savory, spicy, or others.
In bakpia business competition, companies are required to provide innovations in various flavors according to consumer's demand. Drummond \& Brefere (2010) define that flavor is a way of choosing food that must be distinguished from the taste of the food. flavor is a food attribute that includes appearance, smell, taste, texture, and temperature. Flavor is very important in the sale of bakpia.

The results of this study reinforce previous research conducted by Sulistyo (2008) namely "The Influence of Product's Brand, Taste, Packaging Design and Reachability on Instant Noodle Purchases in Yogjakarta (A Case Study on Students of the Universitas Pembangunan Nasional (UPN)" which states that the variable of taste give a significant positive influence on the purchase of instant noodles.

\section{Conclusions}

\subsection{Conclusion}

The flavor has a positive and significant influence on a decision to purchase Bakpia Mutiara Jogja. This is evidenced from the tcount of 3.656, the significance value of 0.000 is smaller than $0.05 \quad(0.000<0.05)$, and the regression coefficient is positive at 0.432 . These findings indicate a sense of influence on purchasing decisions by $32.8 \%$.

\subsection{Suggestion}

It is expected that the company can maintain and improve the flavor of Bakpia Mutiara Jogja because by keeping abreast of consumer's demand and innovating with new tastes so that in the future the purchasing decisions will increase.

\section{References}

Antara News. 2019. Kemenperin: Industri makanan minuman siap penuhi kebutuhan Lebaran. https://www.antaranews.com/berita/1496 860/kemenperin-industri-makanan-minu man-siap-penuhi-kebutuhan-lebaran. Minggu, 17 Mei 2020 09:54 WIB.

Prabudi, Cecep. 2014. Analisis Pengaruh Kualitas Produk Persepsi Harga Dan Citra Merek Terhadap Keputusan Pembelian Produk Bakpia Willis Di Kota Magelang, Semarang Dan Jogjakarta. Skripsi Tidak Diterbitkan. Semarang: UNDIP.

Kotler, Philip. 2002. Marketing Management: 
Analysis, Planning, Implementation, and Control, Tenth Edition. Prentice Hall International, Inc., New Jersey.

Assael, Henry. 2001. Cunsomer Behavior 6th Edition. New York: Thomson-Learning.

Kumastuti, Fitri. (2011). Pengaruh Harga, Atribut Produk dan Promosi Terhadap Keputusan Pembelian Produk Telepon Seluler Sony Ericsson (Studi Kasus di Kabupaten Temanggung). Skripsi Tidak Diterbitkan. Semarang: UNDIP.

Drummond, K. E., \& Brefere, L. M. (2010). Nutrition for foodservice and culinary professionals. New Jersey: John Wiley \& Sons, Inc.

Hasan, Iqbal. 2002. Pokok-Pokok Materi Teori
Pengambilan Keputusan. Jakarta: Ghalia Indonesia.

Simamora, Henry. 2000. Akuntansi Basis Pengambilan Keputusan Bisnis. Jakarta: Salemba Empat.

Sugiyono. 2016. Statistik Untuk Penelitian. Bandung: Alfabeta.

Poerwadarminta, W.J.S. 2010. Kamus Besar Bahasa Indonesia. Jakarta: Balai Pustaka.

Sulistyo. (2008). Pengaruh Merek, Rasa, Desain Kemasan Dan Kemudahan Memperoleh terhadap Pembelian Mie Instan di Yogjakarta (Studi kasus pada Mahasiswa Universitas Pembangunan Nasional (UPN) Veteran Yogyakarta). Jurnal. Yogyakarta: UPN. 